\title{
Corrosion in underground infrastructures
}

\author{
Mukhtar S. \\ University of Chemistry and Technology in Prague, Prague, Czech Republic \\ E-mail: mukhtars@vscht.cz
}

There is a significant loss due to corrosion of buried infrastructure. Many pipes have failed due to mistreatment happening within them all around the world. Different soil aeration leads to macro corrosion cells that cause critical levels within the path corrosion leading to a loss of structural integrity of the buried pipes underground. This review paper seeks to address and presents a predetermined model developed by using software COMSOL Multiphysics to identify and characterize the areas experiencing a high rate of corrosion beneath the surface due to differential aeration. The pipe surfaces experience electrochemical reactions and reactant transport mechanisms in the soil and the pipes. Porosity and degree of saturation make the closed-form equations used to create the mass transport properties and electrical properties that constitute three-phase medium using standard soil parameters. The current model enables the study of soil property variations and conditions from the external environment pipeline corrosion. The model results conclude and agree well with the literature and case studies done at pipeline failure sites. The model used in this review will then enable water utilities to develop forecasting tools that may be useful for assessment.

\section{INTRODUCTION}

It is challenging to locate and predict the pipes buried underground experiencing corrosion because of lack of access to the assets underground [1-3]. Developing an empirically predictive lifetime equation is challenging, mainly because of the difficulties that occurred in data collection over the lifetime of assets that are accurate and contain the relevant variables to use $[4,5]$. To prevent these problems, statistical methods were employed previously to factor and assemble the underground corrosion [1-4] Nonetheless, the effectiveness and the accuracy of the methods rely on field observations and actual valid data [6,7]. Because of the challenges, necessity has been raised to develop a technique to locate and predict the pipelines' overall conditions buried underground [8]. The electrochemical theory can describe the corrosions in soils due to the understanding nature of the approach as an electrolyte and the mechanisms involved $[4,9,10]$. Past researches and evidence show that soil aerations and the differences in aeration play an essential role in indenturing the rates of underground corrosion $[1,4,5]$. Properties of soil such as porosity and saturation are believed to control soil's secondary properties when used as indicators for demining underground corrosion have shown a limited success $[3,6]$. COMSOL Multiphysics as a model considers the direct and indirect ground aeration results to solve the drawbacks encountered in soil corrosion [11-13]. COMSOL Multiphysics puts together diffusion control mechanisms and the areas active of corrosion and dynamics of product corrosion to determine the longterm effects of underground pollution due to differential aeration $[14,15]$.

\section{Underground corrosion and differential aeration}

The formation of macro corrosion couples arises due to a spatial separation of the areas on metal surfaces with different surface potentiality [16,17]. Variations of various soil properties lead to these macro couples within which different aerations can take place [1,4-6]. A shielding effect is created when the formation of insoluble corrosion product occurs $[4,8]$. The metal is affected thermodynamically, preventing the anodic reaction eventually causing macro cell formation $[8,9]$. On the other hand, external features inhibit and promote soil aeration and lead to the cells' formation, causing differential aeration $[18,19]$. An external feature that may lead to that includes the impermeable covers: vegetation, roots, and paving is on the surfaces [20-25]. The waterproof cover formation increases corrosion rate, increasing differential aeration due to the increased ratio of cathode and anode surface area [1,5]. Most of the pipe failures arise due to such localization of corrosion reactions that form corrosion pit [26-30].

\section{COMSOL multiphysics simulation}

The model was developed when a 3D model geometry was created to simulate the pipes' sections experiencing blockage of soils with the waterproof cover 
covering a more extensive surface exposed to the atmosphere [31-35]. The model was brought to perfection by administering constant concentration boundaries condition to the top surface of one of the half of the block $[26,27]$. For example, a situation in which pipes are running through a driveway, which prevents the diffusion of oxygen from the lines inside the covered region and promotes differential aeration cells. Iron is the principal constituent of the pipeline alloys, and thus the anodic reaction is the oxidation of iron [36-40].

$$
\mathrm{Fe}=\mathrm{Fe}^{2}+2 \mathrm{e}
$$

Most soils have neutral to basic conditions, and thus the cathodic reaction was consider the reduction of oxygen [41-45]

$$
\mathrm{O}_{2}+2 \mathrm{H}_{2} \mathrm{O}+4 \mathrm{e}^{-} \rightarrow 4 \mathrm{OH}^{-}
$$

For the underground corrosion, the anodic reaction resulted under control and the cathodic reaction under concentration control.

\section{Soil electrolyte and diffusion of oxygen}

The active area of corrosion is the area in contact with the electrolytes because the soil's interface and the corroding metal are heterogeneous [46]. The area of contact is directly proportional to the bulk soil conductivity [47-50]. Different phases exist in the soil structure, which is solid, liquid, and gases [51]. The solids from the structure with capillary porous characteristics, the liquids, and the gases from the pore structure of the soil. The degree of saturation, the level of compactness of the soil, the porosity change the properties of the threesoil structures [52]. The soil electrolyte will reflect the level of corrosivity of the soil [53]. Soil is characterize by its resistivity and conductivity because soil corrosion is associated with the electrolyte of the soil [44]. Soil is characterized as an electrolyte in a model by forming soil solution $[54,55]$. Furthermore, cathodic control leads to exceeded soil metal corrosions, which proceed in many soils [56]. The limiting oxygen transport caused both cathodic and anodic reactions to the metal surfaces causes the metal in the soil to start corroding [57]. Diffusion is the mode of transport of soil under conditions such as isothermal conditions within the soil structure. The Fick's law modeled diffusion as a mode of transport of oxygen by adjusting diffusion coefficient adjusted to suit the soil factors and elements for the reduction of the area available for diffusion to occur [58-60]. The moisture content and the porosity of the soil affected the rate of diffusion in the soil [61]. Models such as the Millington and the Quirk model occurs in the unsaturated soils and are widely accepted. The perceived diffusion passes only through the air-filled pore in the soil [61-63]. These two models neglect water phase diffusion but on the other hand, accept the air-filled porosity [64]. The diffusion of oxygen through the water contributes to the corrosion process and at a lower rate and smaller percentage as compared to the diffusion of oxygen through the air [65]. Both phases proposed to cause corrosion and they define the dependence of oxygen transportation properties [66].

Moreover, it is well determined that the soil and the metal to experience corrosion come into contact and as result corrosion starts because of coming into contact with the electrolyte $[67,68]$. As an anodic reaction of metals, especially iron require an aqueous medium and for that reason, they cause an active reaction in the soil with soil conductivity [68-70]. The full saturation leads to the highest active area whereas the lowest saturation cause low active areas and the surfaces, therefore, resemblance with the original areas [71]. The active area would be important in measuring the corrosion rates in the electrochemical experiments [72,73]. Electrochemical experiments shown that there is a direct proportion between the active area and the electrical conductivity, so they used to measure, and correct the measured corrosion rates $[74,75]$. When not considering the active surface area, the measured and calculated current density of corrosion was assumed to be disseminated over the whole electrode surface [76,77]. In that way, the overestimation of the current density that measured experimentally to determine the corrosion rate. Modeling the current density attained through experimental work will require the current density to be regulate to suit the active area by using conductivity ratios [78-80]. The modification is therefore included in the anodic terms of density which is currently employed in the corrosion process $[81,82]$.

\section{Time dependent behavior of corrosion products}

Concurrently, the corrosion of products is embedded and dependent on the time behavior [83]. The change in mass of species is related to the current densities according to Faraday's law of electrolysis $[84,85]$. The molar flux of Fe (II) lost by corrosion is converted into a thickness that is defined by the molar mass of species involved and the density of the material $[86,87]$. A decrease in thickness because of corrosion leads to the loss of iron. Besides, the product corrosion deposition has molded as the increasing thickness of the electrode $[88,89]$. The current density of the anodic reaction resulted in the loss of the metal and the current density of the cathodic reaction lead to corrosion product deposition [90]. The shielding effect of corrosion products is molded due to the passivation of the metal surfaces because of the reaction of iron hydroxide and the molar mass and density of the metals $[83,84]$ The surface cover of iron hydroxide corrosion on products [85]. Measures the contribution of active and passive current densities. The sigmoid function has included the effect of passivation currently by the modification of anodic 
current density $[86,87]$. The thickness of the corrosion product on layers formed due to anodic reaction acts as a factor of modifying the passivation [88].

Soil medium characterized by the degree of saturation and the porosity of soil as well as the time-dependent factor [89]. For this reason, COMSOL was used to calculate the electric potential distribution of oxygen concentration and the anodic and cathodic densities which results thereafter on the surface of the transmission pipes $[89,90]$. Differential aeration resulted in the formation of macro corrosion cell on the pipes backed up by electrode potential and the trends of electrolyte potential [88].

\section{CONCLUSION}

Modeling using COMOSOL Multiphysics revealed as a valuable tool to address the underground corrosion influences by differential aeration. Effects of differential aeration and passivation resulting from corrosion products lead to the formation of macro corrosion cells, thus the corrosion of pipes inside with poor access to oxygen. A relationship exists between corrosion mass rates and time-dependent mass loss together with empirical studies. This model has confirmed optimum moisture content for the underground corrosions, mostly studies by many researchers. Finite element models could give valuable insights if they are well combine with experimental shreds of evidence regarding underground pollution.

\section{Acknowledgement}

This work was supported by the Technology Agency of the Czech Republic (TAČR) under project No. TK01010040.

\section{REFERENCES}

1. Norsworthy, R., Understanding corrosion in underground pipelines: basic principles. In Underground Pipeline Corrosion, Elsevier: 2014; pp 3-34.

2. Khosravi, A.; Syri, S.; Zhao, X.; Assad, M. E. H., An artificial intelligence approach for thermodynamic modeling of geothermal based-organic Rankine cycle equipped with solar system. Geothermics 2019, 80, 138-154.

3. Kennedy, M. W.; Akhtar, S.; Bakken, J. A.; Aune, R. E. In Analytical and experimental validation of electromagnetic simulations using $\mathrm{COMSOL}^{\circledR}$, re inductance, induction heating and magnetic fields, COMSOL Users Conference, Stuttgart Germany, 2011; pp 1-9.

4. Escalante, E., Concepts of underground corrosion. In Effects of Soil Characteristics on Corrosion, ASTM International: 1989.

5. Kim, C.-H.; Weston, R. H.; Hodgson, A.; Lee, K.-H., The complementary use of IDEF and UML modelling approaches. Computers in industry 2003, 50 (1), 35-56.
6. Zhang, X.; He, W.; Zhang, Y.; Pandey, M. D., An effective approach for probabilistic lifetime modelling based on the principle of maximum entropy with fractional moments. Applied Mathematical Modelling 2017, 51, 626-642.

7. Petersen, R.; Melchers, R., Long-term corrosion of cast iron cement lined pipes. Corrosion and Prevention 2012, 23 (10).

8. Selwyn, L.; McKinnon, W.; Argyropoulos, V., Models for chloride ion diffusion in archaeological iron. Studies in conservation 2001, 46 (2), 109-120.

9. Tomashov, N. D.; Chernova, G. P., Passivation of Metals by Contact with Cathodes. In Passivity and Protection of Metals Against Corrosion, Springer: 1967; pp 151-179.

10. Rathnayaka, S.; Shannon, B.; Zhang, C.; Kodikara, J., Introduction of the leak-before-break (LBB) concept for cast iron water pipes on the basis of laboratory experiments. Urban Water Journal 2017, 14 (8), 820-828.

11. Andrade, C.; Sanchez, J.; Fullea, J.; Rebolledo, N.; Tavares, F., On-site corrosion rate measurements: 3D simulation and representative values. Materials and Corrosion 2012, 63 (12), 1154-1164.

12. Kranc, S.; Sagüés, A. A., Computation of reinforcing steel corrosion distribution in concrete marine bridge substructures. Corrosion 1994, 50 (1), 50-61.

13. Schwerdtfeger, W., Soil resistivity as related to underground corrosion and cathodic protection. Highway Research Record 1966, (110).

14. Mughabghab, S.; Sullivan, T., Evaluation of the pitting corrosion of carbon steels and other ferrous metals in soil systems. Waste management 1989, 9 (4), 239-251.

15. Wakelin, R. G.; Gummow, R. A., A Summary of the Findings of Recent Watermain Corrosion Studies in Ontario. In Materials Performance Maintenance, Elsevier: 1991; pp 159-175.

16. Deo, R. N.; Birbilis, N.; Cull, J. P., Measurement of corrosion in soil using the galvanostatic pulse technique. Corrosion science 2014, 80, 339-349.

17. Deo, R. N.; Cull, J. P., Spectral induced polarization techniques in soil corrosivity assessments. Geotechnical Testing Journal 2015, 38 (6), 965-977.

18. Mualem, Y.; Friedman, S., Theoretical prediction of electrical conductivity in saturated and unsaturated soil. Water Resources Research 1991, 27 (10), 2771-2777.

19. Rhoades, J.; Raats, P.; Prather, R., Effects of liquid-phase electrical conductivity, water content, and surface conductivity on bulk soil electrical conductivity. Soil Science Society of America Journal 1976, 40 (5), 651-655.

20. Millington, R.; Quirk, J., Permeability of porous solids. Transactions of the Faraday Society 1961, 57, 1200-1207.

21. Aachib, M.; Mbonimpa, M.; Aubertin, M., Measurement and prediction of the oxygen diffusion coefficient in unsaturated media, with applications to soil covers. Water, air, and soil pollution 2004, 156 (1), 163-193.

22. Dang, D. N.; Lanarde, L.; Jeannin, M.; Sabot, R.; Refait, P., Influence of soil moisture on the residual corrosion rates of buried carbon steel structures under cathodic protection. Electrochimica Acta 2015, 176, 1410-1419.

23. Akkouche, R.; Rémazeilles, C.; Jeannin, M.; Barbalat, M.; Sabot, R.; Refait, P., Influence of soil moisture on the corrosion processes of carbon steel in artificial soil: Active area and differential aeration cells. Electrochimica Acta 2016, 213, 698-708. 
24. Chang, Y.-C.; Woollam, R.; Orazem, M. E., Mathematical models for under-deposit corrosion: I. Aerated Media. Journal of The Electrochemical Society 2014, 161 (6), C321.

25. Kim, B. S.; Kang, B. G.; Choi, S. H.; Kim, T. G., Data modeling versus simulation modeling in the big data era: case study of a greenhouse control system. Simulation 2017, 93 (7), 579-594.

26. Gardiner, C.; Melchers, R., Corrosion of mild steel by coal and iron ore. Corrosion science 2002, 44 (12), 2665-2673.

27. Wilkinson, L., Systat. Wiley Interdisciplinary Reviews: Computational Statistics 2010, 2 (2), 256-257.

28. Malki, B.; Baroux, B., Computer simulation of the corrosion pit growth. Corrosion Science 2005, 47 (1), 171-182.

29. Johnson Jr, A. Lessons in metal durability from the ancient metals; 1989.

30. Romanoff, M., Underground corrosion. US Government Printing Office: 1957; Vol. 579.

31. Rajani, B., Investigation of grey cast iron water mains to develop a methodology for estimating service life. American Water Works Association: 2000.

32. Doyle, G.; Seica, M. V.; Grabinsky, M. W., The role of soil in the external corrosion of cast iron water mains in Toronto, Canada. Canadian geotechnical journal 2003, 40 (2), 225-236.

33. Kashani, M. M.; Crewe, A. J.; Alexander, N. A., Use of a 3D optical measurement technique for stochastic corrosion pattern analysis of reinforcing bars subjected to accelerated corrosion. Corrosion Science 2013, 73, 208-221.

34. Fernandez, I.; Bairán, J. M.; Marí, A. R., 3D FEM model development from 3D optical measurement technique applied to corroded steel bars. Construction and Building Materials 2016, 124, 519-532.

35. Deo, R.; Azoor, R.; Kodikara, J. In Proof of concept using numerical simulations for pipe corrosion inferences using ground penetrating radar, $20179^{\text {th }}$ International Workshop on Advanced Ground Penetrating Radar (IWAGPR), IEEE: 2017; pp 1-5.

36. Ashley, G.; Burstein, G., Initial stages of the anodic oxidation of iron in chloride solutions. Corrosion 1991, 47 (12), 908-916.

37. Nicol, M. J.; Zhang, S., Anodic oxidation of iron (II) and copper (I) on various sulfide minerals in chloride solutions. Hydrometallurgy 2016, 166, 167-173.

38. Sasson, M. B.; Calmano, W.; Adin, A., Iron-oxidation processes in an electroflocculation (electrocoagulation) cell. Journal of Hazardous Materials 2009, 171 (1-3), 704-709.

39. Laforce, B.; Fiers, G.; Vandendriessche, H.; Crombé, P.; Cnudde, V.; Vincze, L., Monte Carlo simulation aided quantitative laboratory X-ray fluorescence analysis and its application in provenancing studies for geo-archeological samples. Analytical Chemistry 2021, 93 (8), 3898-3904.

40. Lai, C.; Xie, M.; Murthy, D., Ch. 3. bathtub-shaped failure rate life distributions. Handbook of statistics 2001, 20, 69-104.

41. Venzlaff, H.; Enning, D.; Srinivasan, J.; Mayrhofer, K. J.; Hassel, A. W.; Widdel, F.; Stratmann, M., Accelerated cathodic reaction in microbial corrosion of iron due to direct electron uptake by sulfate-reducing bacteria. Corrosion Science 2013, 66, 88-96.

42. Aldenderfer, M. S., Computer simulation for archaeology: an introductory essay. Simulations in archaeology 1981, $67-118$.
43. Huet, B.; L'hostis, V.; Santarini, G.; Feron, D.; Idrissi, H., Steel corrosion in concrete: Determinist modeling of cathodic reaction as a function of water saturation degree. Corrosion science 2007, 49 (4), 1918-1932.

44. Khaled, K.; Hackerman, N., Investigation of the inhibitive effect of ortho-substituted anilines on corrosion of iron in $1 \mathrm{M} \mathrm{HCl}$ solutions. Electrochimica Acta 2003, 48 (19), 2715-2723.

45. Zerfaoui, M.; Oudda, H.; Hammouti, B.; Kertit, S.; Benkaddour, M., Inhibition of corrosion of iron in citric acid media by aminoacids. Progress in Organic Coatings 2004, 51 (2), 134-138.

46. Dussubieux, L.; Deraisme, A.; Frot, G.; Stevenson, C.; Creech, A.; Bienvenu, Y., La-ICP-ms, SEM-eds and EPMA analysis of eastern north american copper-based artefacts: impact of corrosion and heterogeneity on the reliability of the la-icp-ms compositional results. Archaeometry 2008, $50(4), 643-657$.

47. Dillmann, P.; Neff, D.; Féron, D., Archaeological analogues and corrosion prediction: from past to future. A review. Corrosion engineering, science and technology 2014, 49 (6), 567-576.

48. Libourel, G.; Verney-Carron, A.; Morlok, A.; Gin, S.; Sterpenich, J.; Michelin, A.; Neff, D.; Dillmann, P., The use of natural and archeological analogues for understanding the long-term behavior of nuclear glasses. Comptes Rendus Geoscience 2011, 343 (2-3), 237-245.

49. Azoor, R.; Deo, R. N.; Birbilis, N.; Kodikara, J., On the optimum soil moisture for underground corrosion in different soil types. Corrosion Science 2019, 159, 108116.

50. El-Shamy, A.; Shehata, M.; Ismail, A., Effect of moisture contents of bentonitic clay on the corrosion behavior of steel pipelines. Applied Clay Science 2015, 114, 461-466.

51. Rabus, B.; Wehn, H.; Nolan, M., The importance of soil moisture and soil structure for InSAR phase and backscatter, as determined by FDTD modeling. IEEE transactions on geoscience and remote sensing 2010, 48 (5), 2421-2429.

52. Kodešová, R.; Vignozzi, N.; Rohošková, M.; Hájková, T.; Kočárek, M.; Pagliai, M.; Kozák, J.; Šimůnek, J., Impact of varying soil structure on transport processes in different diagnostic horizons of three soil types. Journal of Contaminant Hydrology 2009, 104 (1-4), 107-125.

53. Ferreira, C. A. M.; Ponciano, J. A.; Vaitsman, D. S.; Pérez, D. V., Evaluation of the corrosivity of the soil through its chemical composition. Science of the total environment 2007, 388 (1-3), 250-255.

54. Rahnemaie, R., Ion adsorption modeling as a tool to characterize metal (hydr) oxide behavior in soil. Wageningen University and Research: $\mathbf{2 0 0 5}$.

55. Maocheng, Y.; Jin, X.; Libao, Y.; Tangqing, W.; Cheng, S.; Wei, K., EIS analysis on stress corrosion initiation of pipeline steel under disbonded coating in near-neutral $\mathrm{pH}$ simulated soil electrolyte. Corrosion Science 2016, 110, 23-34.

56. Neff, D.; Dillmann, P.; Bellot-Gurlet, L.; Beranger, G., Corrosion of iron archaeological artefacts in soil: characterisation of the corrosion system. Corrosion science 2005, 47 (2), 515-535.

57. Cole, I. S.; Marney, D., The science of pipe corrosion: A review of the literature on the corrosion of ferrous metals in soils. Corrosion science 2012, 56, 5-16.

58. Neira, J.; Ortiz, M.; Morales, L.; Acevedo, E., Oxygen diffusion in soils: understanding the factors and processes 
needed for modeling. Chilean journal of agricultural research 2015, 75, 35-44.

59. Nakhaie, D.; Kosari, A.; Mol, J.; Asselin, E., Corrosion resistance of hot-dip galvanized steel in simulated soil solution: A factorial design and pit chemistry study. Corrosion Science 2020, 164, 108310.

60. Schmitz, D.; Anlauf, R.; Rehrmann, P., Effect of air content on the oxygen diffusion coefficient of growing media. 2013.

61. Papachristodoulou, C.; Ioannides, K.; Spathis, S., The effect of moisture content on radon diffusion through soil: assessment in laboratory and field experiments. Health Physics 2007, 92 (3), 257-264.

62. Zhou, D.; Wang, Z.; Li, C., Data requisites for transformer statistical lifetime modelling - Part I: Aging-related failures. IEEE transactions on power delivery 2013, 28 (3), 1750-1757.

63. Partridge, G. P.; Lehman, D. M.; Huebner, R. S., Modeling the reduction of vapor phase emissions from surface soils due to soil matrix effects: porosity/tortuosity concepts. Journal of the Air \& Waste Management Association 1999, 49 (4), 412-423.

64. Cook, F.; Knight, J., Oxygen transport to plant roots: Modeling for physical understanding of soil aeration. Soil Science Society of America Journal 2003, 67 (1), 20-31.

65 . Hussain, R. R.; Ishida, T., Influence of connectivity of concrete pores and associated diffusion of oxygen on corrosion of steel under high humidity. Construction and Building Materials 2010, 24 (6), 1014-1019.

66. Jia, W.; Bao-rong, H., Characteristics of the oxygen reduction in atmospheric corrosion. Chinese Journal of Oceanology and Limnology 1997, 15 (1), 36-41.

67. Stratmann, M., The investigation of the corrosion properties of metals, covered with adsorbed electrolyte layers - A new experimental technique. Corrosion Science 1987, 27 (8), 869-872.

68. Gabreab, E. M.; Hinds, G.; Fearn, S.; Hodgson, D.; Millichamp, J.; Shearing, P. R.; Brett, D. J., An electrochemical treatment to improve corrosion and contact resistance of stainless steel bipolar plates used in polymer electrolyte fuel cells. Journal of Power Sources 2014, 245, 1014-1026.

69. Abbott, A. P.; Frisch, G.; Hartley, J.; Karim, W. O.; Ryder, K. S., Anodic dissolution of metals in ionic liquids. Progress in natural science: Materials international 2015, 25 (6), 595-602.

70. Elsler, B.; Schollmeyer, D.; Dyballa, K. M.; Franke, R.; Waldvogel, S. R., Metal-and Reagent-Free Highly Selective Anodic Cross-Coupling Reaction of Phenols. Angewandte Chemie International Edition 2014, 53 (20), 5210-5213.

71. King, A. D.; Birbilis, N.; Scully, J. R., Accurate electrochemical measurement of magnesium corrosion rates; a combined impedance, mass-loss and hydrogen collection study. Electrochimica Acta 2014, 121, 394-406.

72. Barbalat, M.; Lanarde, L.; Caron, D.; Meyer, M.; Vittonato, J.; Castillon, F.; Fontaine, S.; Refait, P., Electrochemical study of the corrosion rate of carbon steel in soil: Evolution with time and determination of residual corrosion rates under cathodic protection. Corrosion Science 2012, 55, 246-253.

73. Kuş, E.; Mansfeld, F., An evaluation of the electrochemical frequency modulation (EFM) technique. Corrosion Science 2006, 48 (4), 965-979.
74. Féron, D.; Macdonald, D. D., Prediction of long term corrosion behaviour in nuclear waste systems. MRS Online Proceedings Library (OPL) 2006, 932.

75. Birbilis, N.; Buchheit, R. G., Electrochemical characteristics of intermetallic phases in aluminum alloys: an experimental survey and discussion. Journal of the Electrochemical Society 2005, 152 (4), B140.

76. Yi, Y.; Weinberg, G.; Prenzel, M.; Greiner, M.; Heumann, S.; Becker, S.; Schlögl, R., Electrochemical corrosion of a glassy carbon electrode. Catalysis Today 2017, 295, 32-40.

77. Vastag, G.; Szöcs, E.; Shaban, A.; Kálmán, E., New inhibitors for copper corrosion. Pure and Applied Chemistry 2001, 73 (12), 1861-1869.

78. Natarajan, D.; Van Nguyen, T., A two-dimensional, twophase, multicomponent, transient model for the cathode of a proton exchange membrane fuel cell using conventional gas distributors. Journal of the Electrochemical Society 2001, 148 (12), A1324.

79. Meyers, J. P.; Darling, R. M., Model of carbon corrosion in PEM fuel cells. Journal of the Electrochemical Society 2006, 153 (8), A1432.

80. Garcia, I.; Drees, D.; Celis, J.-P., Corrosion-wear of passivating materials in sliding contacts based on a concept of active wear track area. Wear 2001, 249 (5-6), 452-460.

81. Goidanich, S.; Lazzari, L.; Ormellese, M., AC corrosion - Part 1: Effects on overpotentials of anodic and cathodic processes. Corrosion Science 2010, 52 (2), 491-497.

82. Gurvich, M.; Dibenedetto, A.; Ranade, S., A new statistical distribution for characterizing the random strength of brittle materials. Journal of Materials Science 1997, 32 (10), 2559-2564.

83. Wang, K.; Ma, X.; Wang, Y.; He, R., Study on the time-dependent evolution of pitting corrosion in flowing environment. Journal of The Electrochemical Society 2017, 164 (7), C453.

84. Schmidt, G.; Suermann, M.; Bensmann, B.; Hanke-Rauschenbach, R.; Neuweiler, I., Modeling overpotentials related to mass transport through porous transport layers of PEM water electrolysis cells. Journal of The Electrochemical Society 2020, 167 (11), 114511.

85. Scheiner, S.; Hellmich, C., Stable pitting corrosion of stainless steel as diffusion-controlled dissolution process with a sharp moving electrode boundary. Corrosion science 2007, 49 (2), 319-346.

86. Young, D. J., High temperature oxidation and corrosion of metals. Elsevier, Vol. 1, 2008.

87. Graedel, T.; Frankenthal, R., Corrosion mechanisms for iron and low alloy steels exposed to the atmosphere. Journal of the Electrochemical Society 1990, 137 (8), 2385.

88. Ezuber, H. M.; Alshater, A.; Hossain, S.; El-Basir, A., Impact of soil characteristics and moisture content on the corrosion of underground steel pipelines. Arabian Journal for Science and Engineering 2021, 46 (7), 6177-6188.

89. Petersen, R.; Melchers, R., Long-term corrosion of cast iron cement lined pipes. Corrosion and Prevention 2012, $23(10)$.

90. He, B.; Han, P.; Hou, L.; Zhang, D.; Bai, X., Understanding the effect of soil particle size on corrosion behavior of natural gas pipeline via modelling and corrosion micromorphology. Engineering Failure Analysis 2017, 80, 325-340. 